\title{
Kualitas Air Situ Lebak Wangi Bogor Berdasarkan Analisa Fisika, Kimia dan Biologi
}

\author{
Dewi Elfidasari ${ }^{1}$, Nita Noriko ${ }^{2}$, Yunus Effendi ${ }^{3}$, Riris Lindiawati Puspitasari ${ }^{4}$ \\ 1, 2,3,4 Program Studi Biologi, Fakultas Sains dan Teknologi, Universitas Al Azhar Indonesia \\ Jl. Sisingamangaraja, Jakarta 12110
}

Penulis untuk korespondensi/ E-mail: d elfidasari@uai.ac.id

Abstrak - Situ Lebak Wangi merupakan situ yang berada di daerah Bogor, dan awalnya dimanfaatkan sebagai tempat penampungan air saat musim hujan untuk peningkatkan persediaan air tanah. Saat ini, Situ Lebak Wangi dimanfaatkan sebagai tempat pembuangan limbah oleh masyarakat. Hal ini dapat menyebabkan perubahan kualitas baik fisik, kimia dan biologi perairan situ. Untuk itu perlu dilakukan penelitian terhadap kualitas fisik, kimia dan biologi perairan Situ Lebak Wangi agar diperoleh informasi mengenai kualitas perairannya sehingga dapat disosialisasikan kepada masyarakat di sekitarnya nilai penting konservasi, pengelolaan dan pemanfaatan situ tersebut. Hasil pengukuran sifat fisik dan kimia air menunjukkan bahwa suhu di perairan Situ Lebak Wangi masih memenuhi baku mutu air kelas 1, nilai total padatan terlarut perairan Situ masih di bawah ambang batas baku mutu yang dipersyaratkan, nilai kecerahan di perairan Situ Lebak Wangi berkisar antara $67,17-80,83 \mathrm{~cm}$ dengan nilai rata-rata $74,46 \mathrm{~cm}$, nilai $\mathrm{pH}$ perairan danau lebih rendah dari perairan sungai, yaitu berkisar antara 6,60-8-80. Pengukuran DO menunjukkan bahwa di perairan danau konsumsi oksigennya lebih tinggi, sedangkan hasil BOD5 menunjukkan bahwa perairan Situ Lebak Wangi sudah tercemar oleh bahan organik mudah urai (BOD5). Nilai daya hantar listrik berkisar antara 112,0 - 118,0 $\mu$ hos/cm. Hasil analisa kualitas air Situ Lebak Wangi secara keseluruhan menunjukkan bahwa perairan tersebut tidak layak untuk dijadikan sebagai air baku, karena mengandung bakteri patogen Salmonella-Shigella yang merupakan penyebab thypus dan kolera.

Keata Kunci - kualitas fisik, kimia dan biologi; Situ Lebak Wangi; Perairan; Baku mutu air

Abstract - Situ Lebak Wangi is a place located in the Bogor area, and was originally used as a water reservoir during the rainy season to increase groundwater supply. Currently, Situ Lebak Wangi is used as a waste disposal site by the community. This can lead to changes in the quality of both physical, chemical and biological waters there. Therefore, research on the physical, chemical and biological qualities of waters of Situ Lebak Wangi to obtain information about the quality of the waters so that it can be socialized to the community around the importance of conservation, management and utilization of the site. The result of measurement of physical and chemical properties of water shows that the temperature in Situ Lebak Wangi waters still meet the water quality standard class 1 , the total dissolved solids of waters Situ is still below the required quality standard threshold, the brightness value in Situ Lebak Wangi waters ranges between $67,17-80.83 \mathrm{~cm}$ with an average rating of $74.46 \mathrm{~cm}$, the $\mathrm{pH}$ value of the lake waters lower than river waters, which ranged from 6.60-8-80. Measurements of DO indicate that in lake waters oxygen consumption is higher, whereas BOD5 results show that waters Situ Lebak Wangi already contaminated by organic material easily explained (BOD5). The electrical conductivity values range from $112.0-118.0 \mu \mathrm{hos} / \mathrm{cm}$. The result of Situ Lebak Wangi water quality analysis as a whole shows that the water is not feasible to serve as raw water, because it contains Salmonella-Shigella pathogen bacteria which is the cause of thypus and cholera. 
Keywords - physical quality, chemistry and biology, Situ Lebak Wangi, Waters, Water quality standards

\section{PENDAHULUAN}

$\mathrm{S}$ itu Lebak Wangi merupakan salah satu situ yang berada di daerah Bogor. Situ ini awalnya dimanfaatkan sebagai tempat penampungan air di saat musim hujan dan sebagai peningkat ketersediaan air tanah. Situ Lebak Wangi juga dimanfaatkan sebagai tempat pembuangan limbah oleh masyarakat. Akibat dari pemanfaatan yang berlebihan dan pengelolaan yang kurang tepat Situ Lebak Wangi saat ini mengalami pendangkalan karena dijadikan perumahan dan lahan pertanian (Sriyono, 2013). Survei awal memperlihatkan bahwa terjadi peningkatan aktivitas masyarakat di sekitar situ berupa bertambahnya jumlah rumah, area pertanian, restoran dan bengkel serta budidaya perikanan dengan karamba. Selain itu, terjadi pula kemerosotan debit air akibat sedimentasi.

Adanya aktivitas masyarakat di Situ Lebak Wangi diduga menyebabkan terjadinya perubahan kualitas baik fisik, kimia dan biologi pada perairan situ. Perubahan tersebut disebabkan adanya masukan beban dari limbah senyawa organik dan non organik, serta kontaminasi dari septic tank rumah warga sekitar Situ Lebak Wangi yang umumnya mengandung bakteri patogen, khususnya kandungan bakteri total koli dan E.coli (fecal coli) dan dapat membahayakan kesehatan. Masuknya limbah juga dapat menyebabkan blooming algae dan mengubah faktor fisik dan kimia lingkungan perairan.

Perubahan kualitas perairan tersebut menyebabkan penurunan kualitas perairan tersebut tidak sesuai lagi dengan air baku kelas 1 berdasarkan PeraturanPemerintah RI No.82 Tahun 2001 tentang Pengelolaan Kualitas Air dan Pengendalian Pencemaran Air. Berdasarkan permasalahan tersebut perlu dilakukan pengujian secara fisik kimia dan biologi pada air di perairan Situ Lebak Wangi untuk menentukan kualitas air di perairan tersebut.
Penelitian ini bertujuan menentukan kualitas fisik, kimia dan biologi air perairan Situ Lebak Wangi berdasarkan Peraturan Pemerintah RI No.82 Tahun 2001 tentang Pengelolaan Kualitas Air danPengendalianPencemaran Air. Manfaat yang dapat diberikan berupa informasi mengenai kualitas air di Situ Lebak Wangi kepada masyarakat di sekitar kawasan tersebut sehingga dapat dipertimbangkan cara pengelolaan dan pemanfaatan situ tersebut.

\section{TINJAUAN PUSTAKA}

Situ merupakan daerah cekungan seperti danau yang dapat menampung air. Tidak hanya sebagai sumber air, situ juga berfungsi sebagai pengendali banjir, sebagai resapan untuk meningkatkan ketersediaan air tanah dan perikanan. Pemanfaatan situ secara tidak langsung juga telah dilakukan, yaitu sebagai tempat pariwisata dan rekreasi (Yazwar, 2009).

Situ Lebak Wangi adalah salah situ yang berada di daerah Bogor (Gambar 1). Situ ini terletak di Desa Pamegarsari RT 02/01, KecamatanParung, Kabupaten Bogor, Propinsi Jawa Barat. Pemanfaatan yang berlebihan dan pengelolaan yang kurang baik membuat keadaan Situ Lebak Wangi memprihatinkan (Sriyono, 2013).

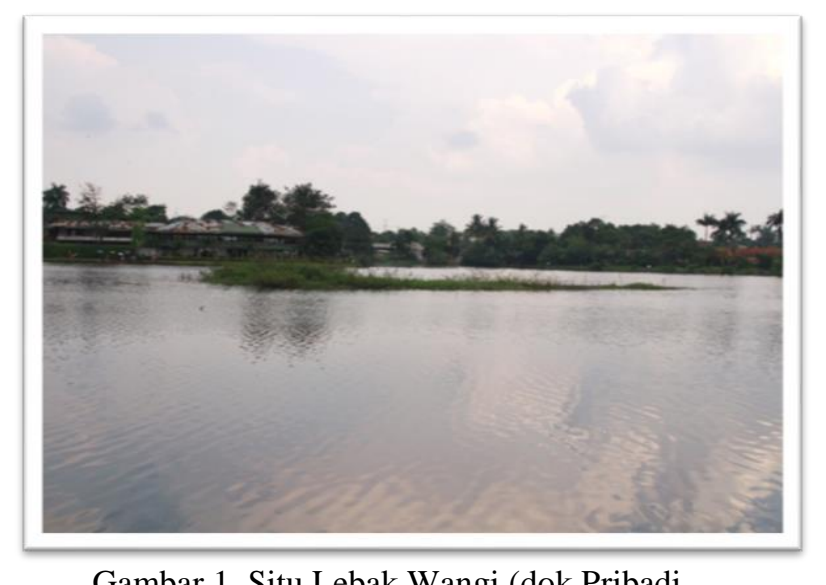

Gambar 1. Situ Lebak Wangi (dok.Pribadi, 2014). 


\section{Faktor Fisik-Kimia Peraira \\ Suhu}

Pengukuran suhu merupakan parameter yang penting dalam perairan, Menurut hokum Van't Hoffs kenaikan suhu sebesar $10^{\circ} \mathrm{C}$ pada kisaran suhu yang masih ditolerir akan meningkatkan aktivitas fisiologis dari suatu organism meningkat 2-3 kali lipat (Barus, 2004). Suhu pada perairan disebabkan oleh intensitas cahaya matahari, kanopi dari vegetasi sekitar perairan serta pertukaran panas antara air dengan udara di sekelilingnya. Kisaran suhu untuk organism perairan adalah sekitar $20-30^{\circ} \mathrm{C}$ (Sitorus, 2009). Peningkatan suhu juga dapat menyebabkan kelarutan oksigen menurun di dalam air (Haslam, 1995).

\section{Derajat Keasaman (pH)}

Derajat keasaman merupakan salah satu faktor pembatas suatu perairan. Perairan umumnya memiliki kisaran tertentu untuk hidup yaitu, netral atau berada pada keadaan asam lemah hingga basa lemah ( $\mathrm{pH}$ 7-8,5). Semakin rendah $\mathrm{pH}$ suatu perairan maka semakin tinggi mobilitas logam berat, sedangkan semakin tinggi $\mathrm{pH}$ perairan menyebabkan keseimbangan ammonium dan ammoniak dalam air terganggu (Barus, 2001) .

\section{Kandungan Oksigen Terlarut (DO)}

Kandungan oksigen terlarut merupakan banyaknya oksigen terlarut dalam suatu perairan. Oksigen terlarut penting bagi organisme perairan terutama respirasi. Proses fotosintesis dari fitoplankton yang menghasilkan oksigen dan difusi dari udara akan mempengaruhi kandungan oksigen terlarut. Faktor lain yang mempengaruhi kandungan oksigen adalah suhu, laju fotosintesis dan adanya zat pencemar lainnya. Konsenrasi oksigen menurun seiring dengan kenaikan suhu dan meningkat seiring dengan penurunan suhu (Barus, 2001).

\section{Kebutuhan Oksigen Biologis $\left(\right.$ BOD $\left._{5}\right)$ dan Kebutuhan Oksigen Kimiawi (COD)}

Kebutuhan oksigen biologis atau Biological Oxygen Demand (BOD) merupakan jumlah oksigen yang diperoleh suatu mikroorganisme aerobic dalam penguraian senyawa organik, yang diukur pada suhu $20^{\circ} \mathrm{C}$. Berdasarkan hasil penelitian, proses penguraian senyawa organik oleh mikroorganisme dapat dilakukan selama 5 hari dengan persentase senyawa organik yang diuraikan mencapai kurang lebih $70 \%$, sehingga pengukuran yang umum dilakukan adalah pengukuran selama 5 hari (BOD 5 ) (Barus, 2001).

Pengukuran BOD didasarkan kepada kemampuan mikroorganisme untuk menguraikan senyawa organik, artinya hanya terdapat substansi yang mudah diuraikan secara biologis seperti senyawa yang umumnya terdapat dalam limbah rumah tangga (Barus, 2001). Menurut Brower et al. (1990), nilai konsentrasi BOD menunjukan suatu kualitas perairan yang masih tergolong baik dimana apabila konsumsi $\mathrm{O}_{2}$ selama periode 5 hari sampai $5 \mathrm{mg} / \mathrm{l} \mathrm{O}_{2}$, dan apabila konsumsi $\mathrm{O}_{2}$ berkisar antara $10 \mathrm{mg} / \mathrm{l}-20 \mathrm{mg} / \mathrm{l}$, maka tingkat pencemaran oleh materi organik tinggi dan untuk air limbah nilai BOD umumnya lebih besar dari $100 \mathrm{mg} / \mathrm{l}$.

Kebutuhan oksigen kimiawi atau Chemical Oxygen Demand (COD) adalah jumlah oksigen yang dibutuhkan dalam proses oksidasi limbah dalam air melalui reaksi kimia (Wardhana, 2004). Perairan yang memiliki nilai COD kurang dari $20 \mathrm{mg} / \mathrm{L}$ termasuk perairan tidak tercemar. Nilai COD untuk perairan yang tercemar yaitu, lebih dari 200 $\mathrm{mg} / \mathrm{L}$ dan pada limbah industry dapat mencapai $60.000 \mathrm{mg} / \mathrm{L}$ (Effendi, 2003).

\section{Total PadatanTerlarut (TDS)}

Total padatan terlarut atau Total Dissolved Solid (TDS) merupakan bahan-bahan terlarut dalam air yang tidak tersaring dengan kertas saring milipore dengan pori $0,45 \mu \mathrm{m}$ (Sitorus, 2009). Padatan ini dapat berupa senyawasenyawa anorganik dan organik yang terlarut dalam air, mineral dan garam-garamnya. Nilai TDS berhubungan dengan kecerahan dan kekeruhan. Kecerahan merupakan kemampuan penetrasi cahaya matahari hingga kedalaman tertentu. Nilai ini penting untuk mengetahui kedalaman tertentu air yang memungkinkan terjadinya proses fotosintesis (Suin, 2002).

\section{Faktor Biologi Perairan Plankton}

Plankton merupakan organism baik tumbuhan maupun hewan yang hidup secara mengapung, mengambang atau melayang di dalam air. Plankton memiliki kemampuan renang yang terbatas sehingga selalu terbawa oleh arus air 
(Nontji 2006). Disribusi plankton sangat dipengaruhi oleh dayagerak air, seperti arus dan lainnya (Nybakken 1992).

Secara fungsional membagi plankton atas empat jenis. Zooplankton atau disebut juga plankton hewani yang umumnya berukuran 0,2-2mm. Jenis plankton ini bersifat heterotrof karena tidak memiliki klorofil. Keberadaannya dipengaruhi oleh fitoplankton sebagai makanannya. Fitoplankton atau dikenal sebagai plankton nabati. Plankton berukuran 2-200 $\mu \mathrm{m}$ dan bersifat fotoautotrof. Fitoplankton merupakan produsen pada ekosistem perairan. Bakterioplankton merupakan bakteri yang hidup sebagai plankton. Berukuran $<1 \mu \mathrm{m}$, tidak berklorofil dan berperan sebagai daur hara dalam ekosistem perairan. Jenis plankton yang terakhir adalah virioplankton, berukuran< $0,2 \mu \mathrm{m}$. Virioplankton menjadikan biota plankton lain sebagai inangnya (Nontji, 2006).

Plankton dalam perairan memegang peranan penting selain sebagai produsen utama. Plankton juga dapat dijadikan sebagai bioindikator atau penentuan kualitas perairan karena plankton mempunyai lingkungan hidup yang sempit dan merespon dengan cepat saat terjadi perubahan pada lingkungan. Salah satu contoh jenis plankton yang menjadi bioindikator terjadinya eutrofikasi adalah Mycrocystis (Belinger\&Sige, 2010).

\section{Coliform}

Coliform merupakan suatu grup bakteri yang digunakan sebagai indikator adanya polusi kotoran dan kondisi yang tidak baik terhadap air, makanan dan produk-produk susu. Coliform sebagai suatu kelompok bakteri dicirikan sebagai bakteri berbentuk batang, Gram negatif, tidak membentuk spora, aerobic dan anaerobic fakultatif yang memfermentasi laktosa dengan menghasilkan asam dan gas dalam waktu 48 jam pada suhu $35^{\circ} \mathrm{C}$. Adanya bakteri Coliform di dalam makanan/minuman menunjukkan kemungkinan adanya mikroba yang bersifat enteropatogenik dan atau toksigenik yang berbahaya bagi kesehatan (Suriawiria, 2008)

Bakteri Coliform dapat dibedakan menjadi 2 kelompok yaitu, fekal dan non fekal. Diantaranya kelompok fekal ini adalah E. coli.
E. coli merupakan bakteri yang berasal dari kotoran hewan atau manusia (Irianto, 2006). Keberadaan E.coli pada air menunjukkan bahwa air tersebut pernah terkontaminasi feses dan mungkin dapat mengandung patogen usus (Servals dan Pierre, 2007). Oleh karena itu, standar air minum mensyaratkan bakteri E.coli harus nol dalam $100 \mathrm{ml}$. Kelompok Coliform non-fekal diantaranya, Enterobacter aerogenes (Suriawiria, 2008).

\section{Penentuan Jumlah Coliform}

Jumlah Coliform dalampemeriksaankualitas air dapat diketahui menggunakan metode MPN (Most Probable Number). Metode MPN mengggunakan medium cair di dalam tabung reaksi, dimana perhitungan dilakukan berdasarkan jumlah tabung yang positif yang ditumbuhi oleh jasad renik setelah diinkubasi pada suhu tertentu. Pengamatan tabung positif terbaik yaitu untuk jasad renik pembentuk gas. Setiap perlakuan pada umumnya digunakan tiga atau lima seri tabung. Lebih banyak tabung yang digunakan menunjukkan ketelitian yang lebih tinggi (Pelzccar dan Chan, 1988).

\section{METODE}

Penelitian dilakukan pada bulan Desember 2014 di Situ Lebak Wangi - Parung Kabupaten Bogor. Pembuatan bahan percobaan dilakukan di Laboratorium Mikrobiologi Prodi Biologi Universitas AlAzhar Indonesia.

Pengambilan sampel air danau dilakukan di 6 titik saat pagi hari (pukul 07.00 - 09.00) dengan 3 ulangan. Posisi pengambilan sampel air ditandai dengan menggunakan alat GPS. Pengambilan sampel menggunakan botol winkler. Botol dimasukkan perlahan ke dalam air. Posisi mulut botol berlawanan dengan arah aliran air sehingga air dapat masuk ke dalam botol tanpa adanya gelembung udara. Botol disimpan dan diberi label untuk analisa fisika dan kimia air danau. Sampel untuk analisis mikroba dilakukan dengan cara mengambil langsung air danau ke dalam botol sampel steril dan segera ditutup rapat lalu disimpan di cool box. 
Pengukuran Faktor Fisik dan Kimia

Sampel air yang disimpan di Botol Winkler segera diukur oksigen terlarut dengan DO meter, suhu air dengan termometer, nilai $\mathrm{pH}$ dengan $\mathrm{pH}$ meter digital, zat padat terlarut dengan TDS meter, dan daya hantar listrik dengan Conductivity meter. Kecerahan air danau dan intensitas cahaya diukur langsung di danau dengan cakra Secchi dan lux meter. Kebutuhan oksigen biokimia (BOD) diukur dengan menghitung selisih nilai DO setelah 5 hari penyimpanan pada suhu $4^{\circ} \mathrm{C}$.

Pembuatan Media

Media dibuat sesuai takaran yang tertera di botol untuk media Plate Count Agar (PCA), Mc Conkey Agar, Escherichia coli Mug Agar, Salmonella-Shiggela Agar (SSA), Potatoes Dextrose Agar (PDA)Media tersebut dilarutkan dalam akuades dan dipanaskan dengan menggunakan penangas air sampai homogen. Kemudian semua media, kecuali SSA, disterilisasi dengan menggunakan autoklaf pada suhu $121^{\circ} \mathrm{C}$ selama 15 menit. Setelah itu, media dituang ke dalam cawan petri dan dibiarkan memadat.

Pengukuran Kualitas Mikrobiologi

Sampel air danau dari ke-6 titik diencerkan dengan menggunakan larutan fisiologis $(\mathrm{NaCl}$ $0,85 \%$ ) hingga pengenceran ke-10. Setelah itu, sebanyak $0,1 \mathrm{ml}$ diinokulasikan ke media uji dan disebar secara merata dengan menggunakan batang L. Setelah itu, diinkubasi di suhu ruang selama 24 jam dan dihitung jumlah koloninya untuk mengetahui jumlah total mikroba. Khusus, untuk pengukuran bakteri Salmonella-Shigella, pengenceran yang ditanam adalah ke-0 sampai dengan ke-3.

\section{HASIL DAN PEMBAHASAN}

\section{Kualitas Fisika dan Kimia Air \\ Suhu air}

Hasil pengukuran suhu pada lokasi penelitian secara keseluruhan tidak memperlihatkan variasi yang besar, bahkan relatif stabil yaitu berkisar antara $29,2-30,2^{\circ} \mathrm{C}$, dengan nilai ratarata $29,6{ }^{\circ} \mathrm{C}$ (Gambar 3). Melihat keadaan suhu di daerah penelitian, dapat disimpulkan bahwa kondisi suhu di perairan Situ Lebak Wangi masih memenuhi baku mutu air kelas 1. Dengan demikian, perairan Situ Lebak
Wangi dapat digunakan sebagai sumber air baku air minum. Suhu air mempunyai peranan dalam mengatur kehidupan biota perairan, terutama dalam proses metabolisme. Kenaikan suhu menyebabkan terjadinya peningkatan konsumsi oksigen, namun di lain pihak juga mengakibatkan turunnya kelarutan oksigen dalam air. Oleh karena itu, maka pada kondisi tersebut organisme akuatik seringkali tidak mampu memenuhi kadar oksigen terlarut untuk keperluan proses metabolisme dan respirasi (Effendi, 2003).

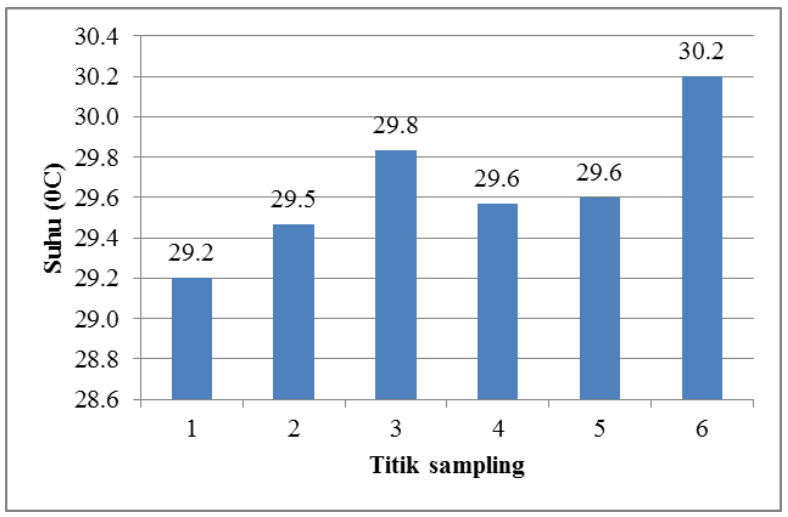

Gambar 2. Sebaran nilai rata-rata suhu di perairan Situ Lebak Wangi.

\section{Zat Padat Terlarut (TDS)}

Hasil pengukuran total padatan terlarut (TDS) di perairan Situ Lebak Wangi berkisar antara 53,67 - 58,67 mg/l dengan rata-rata 56,78 mg/l (Gambar 4). Baku mutu kualitas air kelas 1 berdasarkan PP No. 82 tahun 2001 untuk total padatan terlarut maksimum $1000 \mathrm{mg} / \mathrm{l}$. Nilai total padatan terlarut perairan danau masih di bawah ambang batas baku mutu yang dipersyaratkan. Dengan demikian, perairan Situ Lebak Wangi masih layak digunakan sebagai sumber air baku air minum.

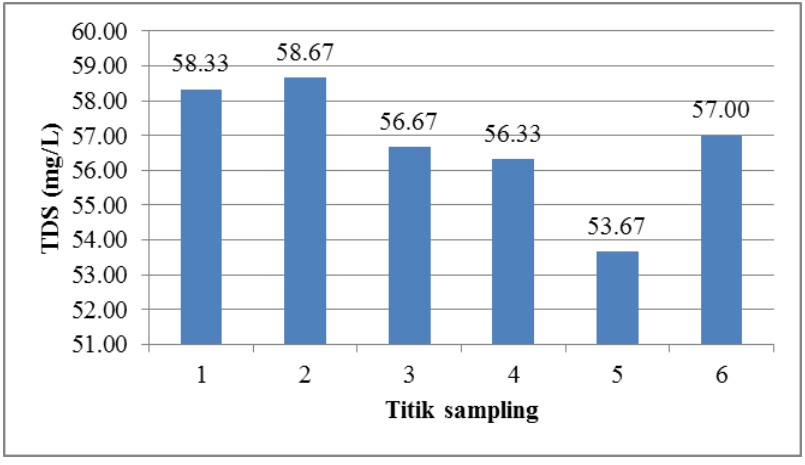

Gambar 3. Sebaran nilai rata-rata zat padat terlarut (TDS) di perairan Situ Lebak Wangi. 


\section{Kecerahan air}

Nilai kecerahan suatu perairan berhubungan erat dengan penetrasi cahaya matahari ke dalam badan air. Cahaya matahari akan membantu proses terjadinya fotosintesis yang akan menghasilkan oksigen terlarut yang merupakan faktor penting dalam kehidupan akuatik. Nilai kecerahan di perairan Situ Lebak Wangi berkisar antara 67,17-80,83 cm dengan nilai rata-rata $74,46 \mathrm{~cm}$ (Gambar 5). Nilai kecerahan antar stasiun penelitian mempunyai variasi yang relatif kecil dan hampir menyebar merata pada setiap stasiun. Adanya perbedaan nilai kecerahan ini diduga karena pengaruh dari kuantitas maupun kualitas air dari daerah aliran sungai yang membawa partikel-partikel bahan organik ke perairan danau.

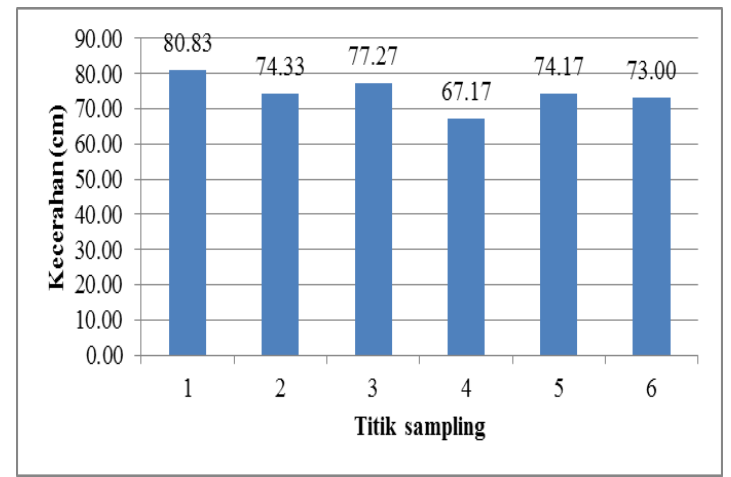

Gambar 4. Sebaran nilai rata-rata kecerahan di perairan Situ Lebak Wangi.

\section{pH air}

Hasil pengukuran $\mathrm{pH}$ di perairan Situ Lebak Wangi memperlihatkan bahwa nilai $\mathrm{pH}$ perairan danau lebih rendah dari perairan sungai, yaitu berkisar antara 6,60-8-80, dengan nilai rata-rata 7,82 (Gambar 5). Hal ini diduga akibat adanya pengaruh buangan limbah penduduk yang masuk ke perairan danau. Limbah atau sampah tersebut mengandung berbagai macam senyawa kimia yang bersifat basa seperti buangan deterjen, yang dapat meningkatkan nilai $\mathrm{pH}$ di perairan. Namun demikian, secara keseluruhan $\mathrm{pH}$ perairan danau masih berada pada kisaran yang aman sebagai sumber air baku air minum berdasarkan ambang batas baku mutu kualitas air kelas 1 yang mensyaratkan nilai $\mathrm{pH}$ antara 6-9. Dengan demikian, $\mathrm{pH}$ perairan Situ Lebak Wangi dapat mendukung kehidupan yang ada di dalamnya dan dapat dipergunakan sebagai sumber air baku air minum.

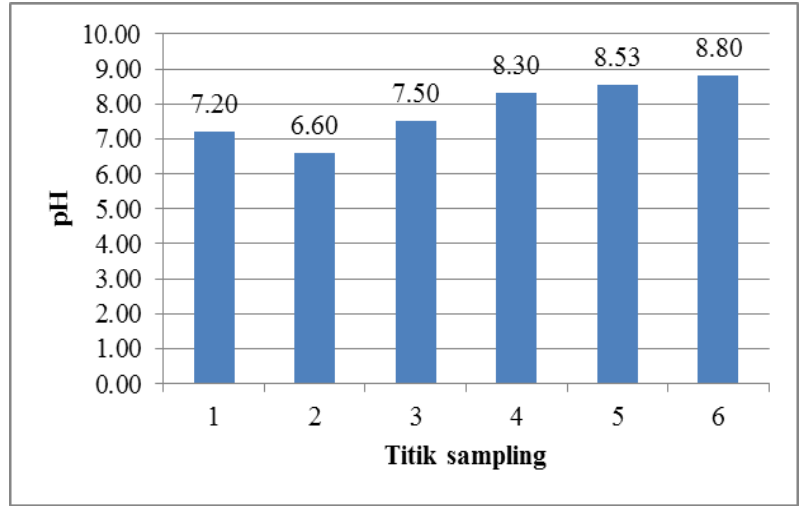

Gambar 5. Sebaran nilai rata-rata $\mathrm{pH}$ di perairan Situ Lebak Wangi.

Nilai $\mathrm{pH}$ dipengaruhi oleh beberapa parameter, antara lain aktivitas biologi, suhu, kandungan oksigen dan ion-ion. Dari aktivitas biologi dihasilkan gas $\mathrm{CO}_{2}$ yang merupakan hasil respirasi. Gas ini akan membentuk ion buffer atau penyangga untuk menjaga kisaran $\mathrm{pH}$ di perairan agar tetap stabil (Pescod, 1978).

\section{Kelarutan Oksigen (DO)}

Hasil pengukuran kandungan oksigen terlarut di perairan Situ Lebak Wangi berkisar antara 4,81 - 6,20 mg/l, dengan nilai rata-rata 5,28 $\mathrm{mg} / \mathrm{l}$ (Gambar 6). Hal ini menunjukkan bahwa di perairan danau konsumsi oksigennya lebih tinggi sebagai akibat dari terjadinya peningkatan jumlah limbah organik yang berasal dari kegiatan di badan perairan danau, terutama kegiatan budidaya ikan dan sampah atau sisa makanan. Kandungan oksigen terlarut di perairan danau tidak melebihi baku mutu air kelas 1 sebagai sumber air baku air minum yang mensyaratkan kandungan oksigen terlarut $>6 \mathrm{mg} / \mathrm{l}$. Kandungan oksigen terlarut ini memberikan gambaran bahwa secara umum perairan danau sudah mulai tercemar oleh bahan organik yang mudah terurai karena nilainya sudah mendekati baku mutu. Hal ini menunjukkkan bahwa perairan danau Situ Lebak Wangi layak digunakan sebagai sumber air baku air minum.

Penyebab kandungan oksigen terlarut di titik sampling 1 di atas ambang batas baku mutu diduga karena padatnya pemanfaatan lahan pada ekosistem perairan danau terutama untuk pertanian, sehingga dekomposisi bahan organik menjadi bahan anorganik oleh mikroorganisme pengurai juga semakin 
meningkat. Selain itu, menurunnya kandungan oksigen terlarut ini juga disebabkan oleh banyaknya limbah organik yang berasal dari limbah domestik dari daerah sempadan danau.

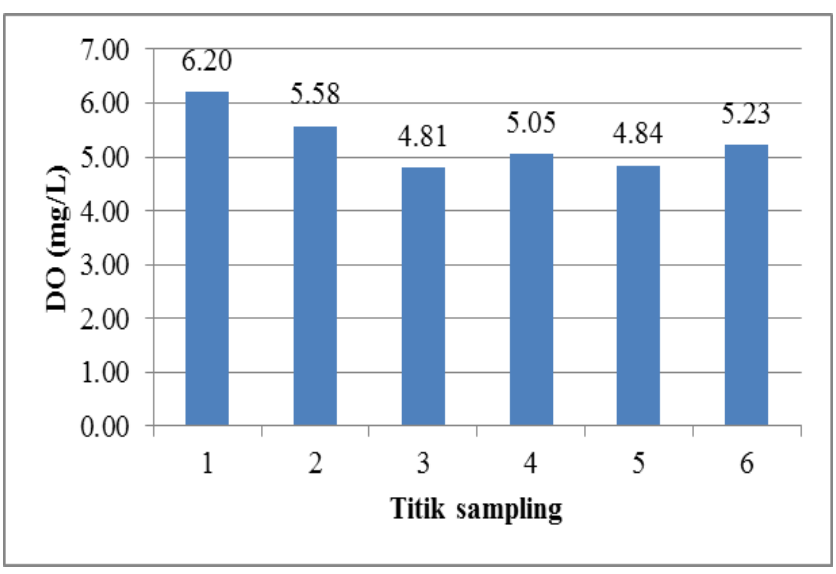

Gambar 6. Sebaran nilai rata-rata kandungan oksigen terlarut di perairan Situ Lebak Wangi.

\section{BOD5}

BOD5 merupakan parameter yang dapat digunakan untuk menggambarkan keberadaan bahan organik di perairan. Hal ini disebabkan BOD5 dapat menggambarkan jumlah bahan organik yang dapat diuraikan secara biologis, yaitu jumlah oksigen terlarut yang dibutuhkan oleh mikroorganisme untuk memecahkan atau mengoksidasi bahan-bahan organik menjadi karbondioksida dan air. Nilai BOD5 yang tinggi menunjukkan semakin besarnya bahan organik yang terdekomposisi menggunakan sejumlah oksigen di perairan. Adapun sebaran nilai rata-rata BOD5 di perairan Situ Lebak Wangi diperlihatkan pada Gambar 7.

Gambar 7 mempresentasikan bahwa nilai BOD5 di perairan danau berkisar antara 1,6$3,1 \mathrm{mg} / \mathrm{l}$, dengan rata-rata $2,4 \mathrm{mg} / \mathrm{l}$. Berdasarkan baku mutu air kelas 1, nilai BOD5 yang dipersyaratkan $<2 \mathrm{mg} / \mathrm{l}$. Dengan demikian, disimpulkan bahwa perairan Situ Lebak Wangi sudah tercemar oleh bahan organik mudah urai (BOD5) dan tidak layak dipergunakan sebagai sumber air baku air minum. Tingginya kadar BOD5 tersebut terutama disebabkan oleh padatnya pemanfaatan areal di sekitar sungai untuk permukiman penduduk. Hal ini akan mengintroduksi limbah domestik masuk ke perairan danau.

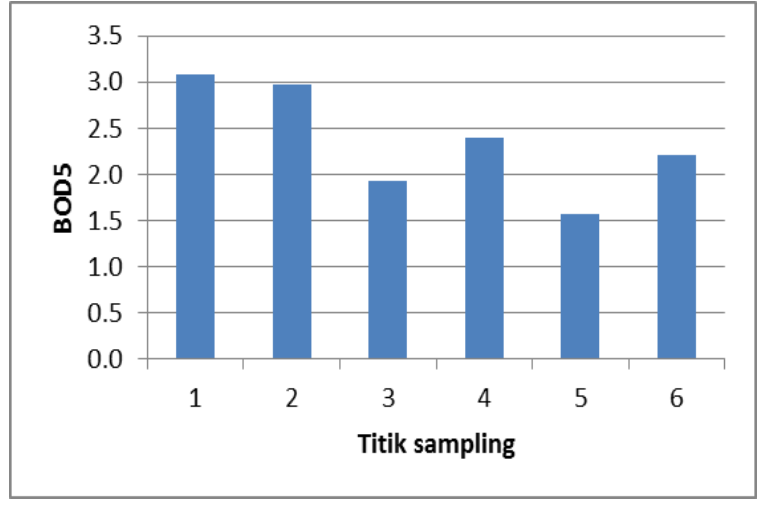

Gambar 7. Sebaran nilai rata-rata BOD5 di perairan Situ Lebak Wangi.

Pada perairan yang relatif tenang (stagnant) seperti Situ Lebak Wangi, limbah organik yang masuk dimungkinkan akan mengendap dan terakumulasi pada subtrat dasar perairan, sehingga proses dekomposisi meningkat dan menyebabkan kandungan oksigen terlarut menurun. Hal ini sesuai dengan pendapat Anggoro (1996) yang menyatakan bahwa menumpuknya bahan pencemar organik di perairan akan menyebabkan proses dekomposisi oleh organisme pengurai juga semakin meningkat, sehingga konsentrasi BOD5 juga meningkat. Di samping itu menurut Canter and Hill (1979), peningkatan nilai BOD5 merupakan indikasi menurunnya kandungan oksigen terlarut di perairan karena adanya aktivitas organisme pengurai.

\section{Daya Hantar Listrik (Conductivity)}

Untuk nilai daya hantar listrik (Conductivity),kondisi air danau Situ Lebak Wangi yang diteliti sebanding dengan kandungan TDS yang mana pada tingkat nilai TDS tinggi, nilai daya hantar listrik juga tinggi (Gambar 8). Hasil pengukuran daya hantar listrik di perairan Situ Lebak Wangi berkisar antara $112,0-118,0 \mu \mathrm{hos} / \mathrm{cm}$, dengan nilai rata-rata rata-rata $114,6 \mu \mathrm{hos} / \mathrm{cm}$. Dalam hal ini tidak ada acuan mengenai persyaratan baku mutu yang ditentukan. Daya hantar listrik sendiri merupakan gambaran mengenai banyaknya kandungan garam-garam terlarut yang mana semakin tinggi ion-ion garamgaram yang ada akan semakin efektif sebagai konduktor dalam mengantarkan arus listrik. 


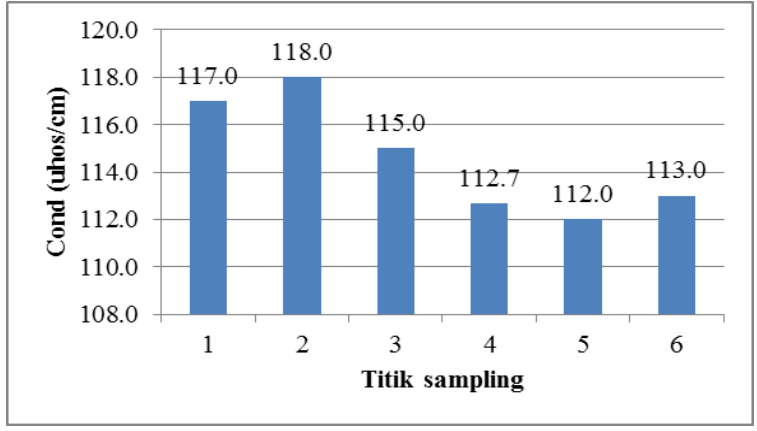

Gambar 8. Sebaran nilai rata-rata daya hantar listrik di perairan Situ Lebak Wangi.

\section{Kualitas Mikrobiologi}

Bakteri coliform dapat digunakan sebagai indikator adanya pencemaran feses atau kotoran manusia dan hewan di dalam perairan. Golongan bakteri ini umumnya terdapat di dalam feses manusia dan hewan. Oleh sebab itu keberadaannya di dalam air tidak dikehendaki, baik ditinjau dari segi kesehatan, estetika, kebersihan maupun kemungkinan terjadinya infeksi yang berbahaya. Beberapa jenis penyakit dapat ditularkan oleh bakteri

Tabel 1. Analisis mikroba perairan Situ Lebak Wangi. coliform melalui air, terutama penyakit perut seperti tipus, kolera dan disentri (Suriawiria, 1993). Hasil analisis kandungan bakteri coliform di perairan danau berkisar antara $1 \mathrm{x}$ $10^{4}-1 \times 10^{7} \mathrm{cfu} / \mathrm{ml}$, yang menunjukkan bahwa perairan Situ Lebak Wangi mengandung bahan organik yang cukup tinggi sebagai sumber kehidupan mikroorganisme. Suriawiria (1993) menyatakan bahwa kehadiran mikroba patogen di dalam air akan meningkat jika kandungan bahan organik di dalam air cukup tinggi, yang berfungsi sebagai tempat dan sumber kehidupan mikroorganisme. Kualitas air Situ Lebak Wangi secara keseluruhan tidak layak untuk dijadikan sebagai air baku, didukung oleh hasil penelitian yang memperlihatkan adanya jenis bakteri patogen Salmonella- Shigella yang merupakan penyebab tifus dan kolera.

\begin{tabular}{|c|c|c|c|c|c|c|c|}
\hline \multirow{2}{*}{ Total } & \multicolumn{5}{|c|}{ Titik sampling } & \multirow{2}{*}{ Rata-rata } & \multirow{2}{*}{$\begin{array}{l}\text { Baku mutu } \\
\text { (CFU/ml) }\end{array}$} \\
\hline & 1 & 2 & 3 & 4 & 5 & & \\
\hline $\begin{array}{l}\text { Bakteri } \\
\text { (CFU/ml) }\end{array}$ & $1 \times 10^{6}$ & $1 \times 10^{6}$ & $1 \times 10^{4}$ & $1 \times 10^{4}$ & $2 \times 10^{12}$ & $4 \times 10^{11}$ & $1 \times 10^{3}$ \\
\hline $\begin{array}{l}\text { E.coli } \\
\text { (CFU/ml) }\end{array}$ & $\begin{array}{l}3.3 \mathrm{x} \\
10^{3}\end{array}$ & $8.8 \times 10^{5}$ & $1 \times 10^{3}$ & $1 \times 10^{3}$ & $4.9 \times 10^{5}$ & $2.8 \times 10^{5}$ & 0 \\
\hline $\begin{array}{l}\text { Coliform } \\
\text { (CFU/ml) }\end{array}$ & $1 \times 10^{5}$ & $1 \times 10^{7}$ & $1 \times 10^{4}$ & $1 \times 10^{5}$ & $1.4 \times 10^{5}$ & $2.1 \times 10^{6}$ & $1 \times 10^{3}$ \\
\hline $\mathrm{SS}(\mathrm{CFU} / \mathrm{ml})$ & $3.3 \times 10^{3}$ & $8.8 \times 10^{5}$ & $1 \times 10^{3}$ & $1 \times 10^{3}$ & $4.9 \times 10^{5}$ & $2.8 \times 10^{5}$ & 0 \\
\hline $\begin{array}{l}\text { Jamur } \\
\text { (propagul/ml) }\end{array}$ & $1.1 \times 10^{2}$ & $1.6 \times 10^{2}$ & $1.8 \times 10^{2}$ & $4.5 \times 10^{1}$ & $2.5 \times 10^{2}$ & $1.5 \times 10^{2}$ & - \\
\hline
\end{tabular}

\section{Fitoplankton}

Hasil peamatan fitoplankton yang dilakukan didapatkan bahwa pada setiap stasiun diperoleh jumlah jenis yang berbeda.

Stasiun 1 ditemukan 15 jenis fitoplankton, sedangkan stasiun 2, 3 dan 4 ditemukan 9, 22 dan 14. Plankton dalam perairan memegang peranan penting selain sebagai produsen utama. Plankton juga dapat dijadikan sebagai bioindikator atau penentuan kualitas perairan karena plankton mempunyai lingkungan hidup yang sempit dan merespon dengan cepat saat terjadi perubahan pada lingkungan. Salah satu contoh jenis plankton yang menjadi bioindikator terjadinya eutrofikasi adalah Mycrocystis (Belinger\&Sige, 2010).

\section{KESIMPULAN}

Berdasarkan pengukuran kualitas fisik, kimia dan mikrobiologi, perairan Situ Lebak Wangi tidak memenuhi baku mutu berdasarkan Peraturan Pemerintah RI No.82 Tahun 2001 tentang Pengelolaan Kualitas Air dan Pengendalian Pencemaran Air. 


\section{UCAPAN TERIMA KASIH}

Dana penelitian ini diperoleh dari Lembaga Pengembangan dan Penelitian (LP2M) Universitas Al Azhar Indonesia.

\section{DAFTAR PUSTAKA}

[1] Barus, T.A. 2001. Pengantar Limnologi: Studi Tentang Ekosistem Air Daratan. Jurusan Biologi. Fakultas Matematika dan IPA. Universitas Sumatera Utara. Medan.

[2] Barus, T.A. 2004. Pengantar Limnologi: Studi Tentang Ekosistem Sungai dan Danau. Jurusan Biologi. Fakultas Matematika dan IPA.Universitas Sumatera Utara. Medan.

[3] Brower, J.E., Jerrold, H.Z. \& Car, I.N.VE. 1990. Field and Laboratory Methods for General Ecology 3th Edition. Wm. C. Brown Publisher. New York.

[4] Effendi, H. 2003. Telaah Kualitas Air: Bagi Pengelolaan Sumber Daya dan Lingkungan Perairan. Kanisius, Yogyakarta.

[5] Fardiaz, S. 1993. Analisis Mikrobiologi Pangan. PAU. IPB.

[6] Haslam, S.M. 1995. River Pollution, An Ecological Perspective. Belhaven Press. London.

[7] Irianto, K. 2006. Mikrobiologi: Menguak Dunia Mikrooganisme. Yrama Widya. Bandung.
[8] Pelczar, M. J. \& E. C. S. Chan. 1986. Dasar-dasar Mikrobiologi. Diterjemahkan oleh : Hadioetomo, R. S., T. Imas, S. S. Tjitrosomo dan S. L. Angka. UI Press. Jakarta.

[9] Servais\& Pierre. 2007. Fecal Bacteria In The Rivers Of The Seine Drainage Network (France): Sources, Fate and Modeling. Université Libre de Bruxelles. Bruxelles.

[10] Sitorus, M. 2009. Hubungan Nilai Produktivitas Primer Dengan Konsentrasi Klorofil $a$ dan Faktor Fisik Kimia Di PerairanDanau Toba, Balige, Sumatera Utara. Tesis. Program Studi Biologi. Sekolah Pasca Sarjana. Universitas Sumatera Utara.

[11] Sriyono, E. 2013. Penelusuran Banjir dan Kapasitas Pelimpah Situ Lebak Wangi, Bogor Jawa Barat. Jurnal Teknik. 2(3): 84-91.

[12] Suin, N. M. 2002. Metode Ekologi. Universitas Andalas. Padang.

[13] Suriawiria, U. 2008. Mikrobiologi Air. PT. Alumni. Bandung.

[14] Wardhana, W.A. 2004. Dampak Pencemaran Perairan, Penerbit Andi, Yogyakarta.

[15] Yazwar. 2008. Keanekaragaman Plankton Berdasarkan dan Keterkaitannya Dengan Kualitas Air Di Prapat Danau Toba. Tesis. Program Studi Biologi. Sekolah Pasca Sarjana Universitas Sumatera Utara. Universitas Sumatera Utara. 